\title{
TONSKO SNIMANJE ROČIŠTA PRED SUDOVIMA FEDERACIJE BOSNE I HERCEGOVINE
}

\author{
Prof. dr. sc. Jozo Čizmić* \\ Izv. prof. dr. sc. Marija Boban**
}

\author{
UDK: $347.91 / .95$ \\ https://doi.org/10.30925/zpfsr.40.1.3 \\ Ur.: 7. siječnja 2019. \\ Pr.: 26. siječnja 2019. \\ Izvorni znanstveni rad
}

\begin{abstract}
Sažetak
Člankom 98. Novele Zakona o parničnom postupku Federacije Bosne i Hercegovine iz 2015. godine dopunjen je postojeći zakonski tekst novim člancima 375 a, $375 b$. i 375c. kojima se uvodi mogućnost tonskog snimanja ročišta u parničnom postupku. Predloženim člancima regulira se način postupanja suda pri provođenju tonskog snimanja, a svrha je unapređenje učinkovitosti sudskog postupka i veća vjerodostojnost dokaznog postupka. U radu su se autori osvrnuli na: razloge i cilj reguliranja tonskog snimanja ročišta u parničnom postupku, način i postupak donošenje odluke o tonskom snimanju ročišta, pohranu snimljenog tonskog zapisa, izradu prijepisa tonskog zapisa i mogućnost prigovora stranke te druge relevantne propise kojima se uređuje tonsko snimanje sudskih rasprava (Zakon o kaznenom postupku, upute sudova $i$ sudski poslovnik). U zaključku je ukazano na niz problema koji otežavaju $i$ onemogućavaju tonsko snimanje ročišta u parničnom postupku s prijedlozima kako takav način dokumentiranja tvrdnji o činjenicama, iskazima i izjavama sudionika u parničnom postupku učiniti učinkovitijim.
\end{abstract}

Ključne riječi: tonsko snimanje; ročište; informacijsko-komunikacijska tehnologija (IKT); parnični postupak.

\section{1. $U V O D$}

Parlament Federacije Bosne i Hercegovine na sjednici Predstavničkog doma od 27. listopada 2015. godine i na sjednici Doma naroda održanoj 19. studenog 2015. godine usvojio je Zakona o izmjenama i dopunama Zakona o parničnom postupku Federacije Bosne i Hercegovine (dalje - Novela), a objavljen je u Službenim novinama Federacije Bosne i Hercegovine“, broj 98/15, od 23. prosinca 2015. godine, te je stupio na snagu 31. prosinca 2015. godine.

* Dr. sc. Jozo Čizmić, redoviti profesor u trajnom zvanju, Pravni fakultet Sveučilišta u Splitu; jozo.cizmic@pravst.hr.

** Dr. sc. Marija Boban, izvanredna profesorica, Pravni fakultet Sveučilišta u Splitu; marija. boban@gmail.com. 
Što se razloga za donošenje Novele tiče, zakonodavac je, analizirajući postojeće zakonsko rješenje u području provođenja parničnog postupka, te uzevši u obzir sve činjenice koje ukazuju na određene nejasnoće i nepreciznosti u postojećim zakonskim odredbama, pristupio izradi Novele kako bi se postiglo kvalitetno zakonsko rješenje. Kako je sam predlagatelj tvrdio, pritom su uzete u obzir mnoge primjedbe i preporuke proizašle iz konkretnih slučajeva u sudskoj praksi, a posebno one koje su se odnosile na neprecizne formulacije pojedinih zakonskih normi, pri čemu je dolazilo do mnogih dvojbi u primjeni i odugovlačenja postupka. Potreba za doradom i unaprjeđenjem važećeg zakonskog teksta proizašla je iz njegove višegodišnje primjene, s obzirom na to da se je kroz duže vremensko razdoblje pokazalo nedostatnim važeće zakonsko rješenje za pojedine životne probleme koji se stavljaju pred sudove radi njihovog rješavanja u parničnom postupku, a koji nisu normirani ili su djelomično normirani u važećem tekstu. ${ }^{1}$

Ipak, neke su od novina uvedene bez uvažavanja postojećeg stanja u pravosuđu, ponajprije kadrovskog, materijalnog, financijskog i informatizacijskog potencijala pravosudnog aparata, te činjenice postojanja velikog broja zaostalih neriješenih predmeta pa je za neke odredbe unaprijed moglo biti jasno da ih sudovi neće moći učinkovito primjenjivati (primjerice, neke odredbe o rokovima, dostavi, tonskom snimanju i sl.). ${ }^{2}$

Jedno od područja u građanskom procesnom pravu koje prije donošenja Novele nije bilo regulirano je upravo tonsko snimanje ročišta u parničnom postupku. S druge strane, tonsko snimanje ročišta u kaznenim predmetima bilo je regulirano davno prije toga. Novelom je omogućeno i snimanje ročišta u parničnim predmetima. Novim člancima se modernizira Zakon o parničnom postupku Federacije Bosne i Hercegovine („Službene novine Federacije Bosne i Hercegovine“, broj 53/03, 73/05 i 19/06, 98/15., dalje - FZPP) koji do sada nije sadržavao odredbe o mogućem fotografskom, filmskom i drugom snimanju sudskog postupka. Držalo se kako će se time zasigurno odgovoriti na probleme koji su se pojavili u praksi, a koji se odnose na: mogućnost snimanja parničnog sudskog postupka, osobe koje su ovlaštene odobriti takva snimanja, zaštitu osobnih podataka o strankama i drugim sudionicima u postupku uz propisano korištenje za potrebe sudskog postupka kako bi se onemogućile zlouporabe. ${ }^{3}$

1 Treba napomenuti da je i u Republici Srpskoj 2013. godine donesen Zakon o izmjenama i dopunama Zakona o parničnom postupku Republike Srpske, objavljen u „Službenom glasniku RS“, broj 61/13 od 19. 7. 2013., koji je gotovo istovjetnog sadržaja i rješenja kao i ova novela ZPP-a Federacije iz 2015. godine. Odredbe novele ZPPRS i Novele FZPP-a su gotovo identične, uz neznatne pojmovne, jezične i nomotehničke razlike te razlike uvjetovane drukčijom organizacijom i nazivljem u pravosudnim sustavima entiteta.

2 Vidi Prijedlog zakona o izmjenama i dopunama Zakona o parničnom postupku Federacije Bosne i Hercegovine sa Obrazloženjem, Vlada Federacije Bosne i Hercegovine, Sarajevo, juni 2015. godine, dalje - Prijedlog Novele, str. 36.

3 Tako Uprava za građansko pravo, Odjel za propise građanskog procesnog prava, Radnoj grupi za izradbu Nacrta prijedloga zakona o izmjenama i dopunama Zakona o parničnom postupku, Obrazloženje uz čl. 42, str. 31. 


\section{RAZLOZI I CILJ REGULIRANJA TONSKOG SNIMANJA ROČIŠTA}

Kao jedan od mogućih i zakonom dopuštenih načina dokumentiranja iznesenih činjenica, izjava i iskaza tijekom ročišta, moguće je dokumentiranje putem unošenja iznesenih činjenica, izjava $\mathrm{i}$ iskaza usmeno na zapisnik $\mathrm{i}$ to na način da stranke $u$ postupku iznose svoje činjenične tvrdnje, koje tehničko osoblje (zapisničar) uz dopuštenje postupajućega suca, zapisničarskim tipkanjem unosi na zapisnik. Sve te činjenice, informacije i izjave vrlo se često unose po načelu interpretacije na način da postupajući sudac u pravilu interpretira ono što su stranka, njezin punomoćnik, svjedok ili vještak rekli ili imali namjeru kazati, na način da sudac usmeno diktira na zapisnik prepričavajući dati iskaz koji se unosi u zapisnik. Prilikom interpretacije iskaza ostavlja se mogućnost i prostor za ponekad pogrešnom interpretacijom koja za posljedicu može imati i zapisničko evidentiranje onoga što je suprotno od onoga što su stranka ili svjedok željeli misaono istaknuti. Stranke na kraju ročišta potpisom potpisuju zapisnik kao znak da su upoznate sa sadržajem zapisnika i istim tim potpisom potvrđuju da sve ono što je navedeno u zapisniku je autentično s onim što je usmeno izneseno tijekom ročišta. Međutim praksa je pokazala da stranke u postupku potpisuju zapisnik a da ga uopće nisu prethodno ni pročitale, a tek kasnije naknadnim uvidom u spis utvrde da je nešto što smatraju bitnim ispušteno iz zapisnika ili eventualno je neka iznesena činjenica pogrešno interpretirana, što stvara probleme i sudu i strankama. Stoga se slobodno može konstatirati da je ovakav način dokumentiranja na zapisnik izjava i činjenica iznesenih tijekom ročišta nedovoljno odgovarajući i navedeni način ostavlja prostor za sumnju i manipulaciju. Međutim, također se sa žaljenjem mora konstatirati da je upravo ovakav način dokumentiranja svih usmeno iznesenih činjenica, izjava iskaza tijekom ročišta masovno zastupljen pred sudovima u parničnim postupcima. Za razliku od usmenog interpretiranja iznesenih činjenica izjava i iskaza upisivanjem u zapisnik, drugi način evidentiranja izjava iskaza te činjeničnih tvrdnji usmeno iznesenih tijekom ročišta moguće je i putem tonskog snimanja, koje također predstavlja jedan od zakonom dopuštenih načina evidentiranja i dokumentiranja kronologije događanja tijekom pripremnog ročišta ili ročišta za glavnu raspravu. Tonskim snimanjem, kao jednim od načina tehničkog dokumentiranja, vrši se zapis svih činjenica, navoda i iskaza iznesenih tijekom ročišta.

Člankom 98. Novele dopunjen je zakonski tekst FZPP-a novim člancima 375a, 375b. i 375c. kojima se uvodi mogućnost tonskog snimanja ročišta. Predloženim člancima regulira se način postupanja suda prilikom provođenja tonskog snimanja, a svrha je unapređenje učinkovitosti sudskog postupka i veća vjerodostojnost dokaznog postupka. ${ }^{4}$ Diktiranje u zapisnik tijeka rasprave znatno odugovlači njezino trajanje i iscrpljuje sve sudionike, a posebno predsjednika vijeća koji, nakon praćenja izjava sudionika i iskaza osoba koje ispituje, u zapisnik mora unijeti njihov bitni sadržaj pa bi snimanje rasprave, ako ne postoji obveza ,paralelnog“ vođenja zapisnika kao da se rasprava ne snima, nedvojbeno dovelo do skraćivanja njezinog trajanja, a time i do

$4 \quad$ Usp. Prijedlog Novele, Obrazloženje, str. 51. 
povećanja učinkovitosti sudstva. ${ }^{5}$

Cilj ove nove mogućnosti je ubrzanje postupka na način da se sud rastereti od unošenja izjava datih na ročištu na zapisnik, te ujedno da se omogući što točnije bilježenje onoga što je rečeno na ročištu, što doprinosi vjerodostojnosti dokaznog postupka. ${ }^{6}$ Snimanje rasprave trebalo bi omogućiti odražavanje njezinog stvarnog tijeka i registriranje svih zbivanja u sudnici, što sa zapisnikom često nije slučaj. Kao što dvije osobe nikad ne bi istim riječima i na isti način opisale jedan događaj, tako niti dva suca ne bi na jednaki način reproducirali u zapisnik bitni sadržaj jednog iskaza ili neko drugo zbivanje u sudnici, zbog čega se nerijetko događa i da stranke (u pravilu već tijekom diktiranja zapisnika) stavljaju prigovore na sadržaj zapisnika, bilo o tome što bi iz iskaza ispitane osobe trebalo unijeti u zapisnik pošto stranka smatra da se radi o važnom dijelu iskaza a predsjednik vijeća to nije našao, bilo o tome što je ispitana osoba zapravo iskazala. Snimanje rasprave otklonilo bi takve primjedbe. ${ }^{7}$ Snimanje tijeka rasprave omogućilo bi i provjeru pravilnosti i potpunosti procesnih upozorenja sudionicima u postupku i stvarnog sadržaja njihovih procesnih izjava. Drži se da tonsko snimanje bitno ubrzava odvijanje ročišta zbog otpadanja potrebe za ponavljanjem - diktiranjem pa je moguća učinkovitija koncentracija raspravnog gradiva, odnosno moguće je smanjiti broj ročišta. Osim toga, snimljeni materijal omogućava drugostupanjskom sudu točniji uvid u raspravno gradivo, što u većoj mjeri omogućava i suđenje u drugom stupnju. Dakle, realna je pretpostavka da je uvođenje tonskog snimanja kvalitetan pomak naprijed u pokušajima poboljšanja učinkovitosti građanskopravnog sudovanja. ${ }^{8}$

Financijskim ulaganjem od strane domaćih vlasti i stranih država, kao oblika pomoći $\mathrm{BiH}$ u reformi pravosuđa, sudovi su opremljeni suvremenim tehničkim sredstvima (računala, računarske mreže i serveri, pojedinačni i mrežni printeri, skeneri i dr.), bazični programi (software) su licencirani, omogućen je pristup internetu, a svaki sudac i službenik suda ima kompletnu PC konfiguraciju i osobnu e-mail adresu. Glavni ciljevi prema kojima je proces informatizacije pravosuđa Bosne i Hercegovine kontinuirano težio su pravodobno i učinkovito pružanje kvalitetnih usluga, i povećanje transparentnosti rada bosanskohercegovačkih sudova i tužiteljstava. Sve inovacije, aktivnosti i radnje su realizirane s namjerom donošenja dodatne koristi krajnjim korisnicima. Kako bi unaprijedili ove opće ciljeve, definirani su i konkretni podciljevi: povezivanje pravosudnih institucija sa drugim relevantnim tijelima, brza i učinkovita podatkovna razmjena, jeftinije sudske usluge; smanjenje broja osnovnih sudskih pogrešaka; standardizacija podataka; podsjetnici za sudsko

5 Vidi Tripalo, D., Snimanje ispitivanja osumnjičenika i snimanje rasprave prema prijedlogu ZID ZKP iz 2017. (7. Novela), rad u zborniku ur. A. Garačić i dr., Novine u kaznenom zakonodavstvu - 2017., Opatija, 11.-12. svibnja 2017., str. 82.

6 Tako Prijedlog izmjena i dopuna Zakona o parničnom postupku, Radna grupa za izmjene i dopune ZPP U BiH, RS, FBiH i Brčko Distriktu BiH, Ilidža - 4. i 5. 2012. godine, dalje Prijedlog 2012., str. 68.

7 Usp. Tripalo, D., op. cit., str. 82.

8 Vidi Bilić, V., Troškovi postupka, dostava i tonsko snimanje glavne rasprave prema Zakonu o izmjenama i dopunama ZPP-a 2011., u knjizi: Bilić, V. i dr., Novela Zakona o parničnom postupku iz 2011, Zagreb, Novi informator, 2011, str. 80. 
osoblje; zamjena papirnatih spisa elektroničkim; kreiranje baze podataka; efikasnije pružanje informacija i osnovne pravne pomoći građanima; fleksibilnije radno vrijeme i implementacija sustava za audio i vizualno snimanje. ${ }^{9}$

Svaki sud ima opremu za tonsko snimanje u kaznenom postupku. Zbog postojanja tehničkih i tehnoloških uvjeta za snimanje tijeka rasprave, zakonodavac se opredijelio zakonom urediti to pitanje i $\mathrm{u}$ parničnom postupku. ${ }^{10}$ Primjenom informacijsko-komunikacijske tehnologije u parničnom postupku ostvaruju se brojne prednosti od kojih su najvažnije povećanje transparentnosti, brža dostupnost informacijama, olakšani pristup pravosuđu i ubrzanje postupka. Osim toga, informatizacijom parničnog postupka, odnosno informatizacijom svih građanskih sudskih procedura postižu se brojni racionalizirajući učinci za pravosuđe u cjelini i ostvaruju se značajne uštede. Naime, uspješnost primjene informacijske tehnologije ovisi o nizu elemenata kao što su odabrani zakonodavni okvir, jedinstveno (zemaljski ili kantonalno nepodijeljeno) uređenje, osiguranje znatnih financijskih sredstava za opremu, obrazovanje, pohranu i elektronički potpis. ${ }^{11}$ Iako je svrha tonskog snimanja ročišta ubrzati proceduru, u primjeni su se mogle očekivati poteškoće u početnom uhodavanju - rukovanju s novom opremom, preraspodjeli poslova zapisničara i sl.

Tonsko snimanje kao procesna mogućnost poznata je u većini europskih zemalja i znatno olakšava i čini vjerodostojnijim dokazni postupak. Dakako, za to trebaju postojati tehnički preduvjeti te se ova mogućnost uvodi postupno, odnosno nakon što pojedini sud stekne uvjete za to. ${ }^{12}$ Tonsko snimanje rasprava otvoreno je tek kao mogućnost - ono nije obvezatno. Operacionalizacija odredaba o tonskom snimanju

9 Neposredno prije uvođenja informacijsko-komunikacijskih tehnologija (IKT) u pravosudni sistem, sudovi i tužiteljstva su imali tek nešto više od 500 kompjutera na kojima skoro uopće nije bilo licenciranog softvera. Evidencije u predmetima vođene su ručno, a da bi se dobila neka informacija bilo je neophodno pregledati brdo papirnatih spisa. VSTV BiH je 2004. godine, usvajanjem Strategije informatizacije pravosuđa $\mathrm{BiH}$, započeo proces mijenjanja načina funkcioniranja pravosudnih institucija koji se nije važnije promijenio od početka 20 . stoljeća. Motiv iza donošenja ove strategije je bio utemeljen na činjenici da bez IKT-a pravosuđe ne bi bilo u mogućnosti pružiti kvalitetne i moderne usluge, koje bi mogle odgovoriti potrebama društva, zbog čega je VSTV BiH pokrenuo proces informatizacije pravosuđa kroz uspostavu neophodne infrastrukture, te uvođenja suvremenih i potrebama pravosuđa prilagođenih IKT rješenja. Provodeći proces informatizacije pravosuđa u BiH, VSTV je uvijek bio rukovođen krajnjim ciljevima ovog procesa, točnije: pravodobnim i učinkovitim pružanjem kvalitetnih usluga, i povećanjem transparentnosti rada bih sudova i tužilaštava. Sve inovacije i aktivnosti u procesu informatizacije pravosuđa realizirane su s namjerom da donesu dodatnu korist krajnjim korisnicima, odnosno građanima Bosne i Hercegovine. Vidi Počeci informatizacije pravosuđa u Bosni i Hercegovini, podatak na stranici: https://www.pravosudje.ba/vstv/faces/vijesti. jsp?id=68508; posjet 27. 12. 2018

10 Usp. Kulenović, Z., Zakon o parničnom postupku Republike Srpske, Domaća i strana sudska praksa - stručni i informativni časopis, godina XI, 60/2014, str. 43.

11 Tako Maganić, A., Elektroničko vođenje postupka, u knjizi: Mihajlo D. i dr., Novosti u parničnom postupku - Zakon o izmjenama i dopunama Zakona o parničnom postupku (NN br. 57/11), Zagreb, Organizator d.o.o., 16. lipnja 2011, str. 73. Inače, u Sloveniji se pokazalo da je jedan sat rasprave šest sati za prepisivače, pa se može očekivati porast opsega posla zapisničara.

12 Vidi Kontrec, D., Žalba protiv presude, u knjizi Bilić, V. i dr., Novela Zakona o parničnom postupku iz 2011., Zagreb, Novi informator, 2011, str. 84. 
višestruko je uvjetovana. Ponajprije takvo snimanje je potrebno razraditi odredbama Sudskog poslovnika, ${ }^{13}$ kao što je i predviđeno odredbom st. 2. čl. 375b. FZPP-a.

\section{DONOŠENJE ODLUKE O TONSKOM SNIMANJU ROČIS̆TA}

Odredbom članka 375a. FZPP-a uvodi se u parnični postupak mogućnost tonskog snimanja ročišta, o čemu odlučuje sud rješenjem, svojom inicijativom ili na prijedlog stranke. Također se određuje da protiv toga rješenja nije dopuštena žalba, te da se tonska snimke mora dostaviti strankama.

Specifičnost ovog načina tehničkog dokumentiranja ogleda se u vrlo bitnoj činjenici što se tonskim zapisom na autentičan i izvoran način dokumentira svaka usmeno iznesena činjenična tvrdnja parničnih stranaka i iskaz tijekom postupka, upravo onakav kakav je stranka u postupku i istaknula. Upravo ta autentičnost $\mathrm{i}$ izvornost tehničkog dokumentiranja činjeničnih tvrdnji i izjava putem tonskog snimanja daju jamstvo izvornosti i istovjetnosti onih činjenica koje su stranke u postupku iznijele a koje dokazuju osnovanim tužbeni zahtjev ili isti osporavaju kao neutemeljen. Stoga se može zaključiti da tonsko snimanje kao način tehničkog dokumentiranja svih iznesenih činjenica tijekom ročišta predstavlja odgovarajući i prihvatljiv način zapisničkog evidentiranja svega onoga što su stranke iznijele tijekom parničnog postupka.

Tonska snimke (ročišta) ima višestruku važnu ulogu u parničnom postupku. On je pomoćno sredstvo suda pri sastavljanju zapisnika, kao dokazno sredstvo on je predmet očevida, pretpostavlja prihvaćanje i primjenu europskih standarda $u$ bosanskohercegovačkom procesnom pravu, kao procesna mogućnost poznato je u većini europskih zemalja, olakšava i čini vjerodostojnijim dokazni postupak i sl.

Ročišta pred sudom mogu se tonski snimati, a o tonskom snimanju rješenjem odlučuje sud sam ili na prijedlog stranke. Dakle, radi se o opciji, mogućnosti koju sudac može (a ne mora) koristiti, ${ }^{14}$ a ne o procesnoj dužnosti. Hoće li se ta mogućnost realizirati ili ne, ovisi o odluci suca pojedinca ili predsjednika vijeća koji će o tome odlučiti rješenjem ex officio ili u povodu prijedloga stranke. ${ }^{15}$ Držimo dobrim rješenjem što je zakonodavac u st. 2. ostavio mogućnost da sud odlučuje o tonskom

13 Tako i podrobnije kod Dika, M., Novela Zakona o parničnom postupku iz 2011. - Opći pregled, u knjizi Bilić V. i dr., Novela Zakona o parničnom postupku iz 2011., Zagreb, Novi informator, 2011, str. 24.

14 Usp. Bilić, V., op. cit., str. 79.

15 Tako je u jednom predmetu pred Višim (Apelacijskim) sudom u Novom Sadu pripremno ročište zakazano za 20. 11. 2014. godine "ali nije održano zbog protesta i obustave rada advokata, kao ni naredno ročište zakazano za 20. 01. 2015. godine. Po okončanju protesta advokata, ročište je zakazano za 07. 04. 2015. godine ali je prekinuto na zahtev tužioca jer nije udovoljeno njegovom zahtevu za tonsko snimanje, za koje sud nije imao tehničkih uslova. Proverom u upravi Višeg suda u Novom Sadu postupajući sudija je utvrdio da ne postoje tehnički uslovi za audio i video snimanje ročišta o čemu je obavešten i tužilac. I naredno ročište zakazano za 19.06.2015. godine je takođe odloženo na predlog tužioca, koji je insistirao na tonskom snimanju, zahtevajući da sud nakon obezbeđenja tonskog snimanja, odluči o dinamici izvođenja dokaza”. Vidi odluku: Apelacioni sud u Novom Sadu, Broj: Ržr-1/17, Datum: 19. 06. 2017. godine. 
snimanju ročišta i na prijedlog ,stranke“, a ne „stranaka“ kao što je to odredio hrvatski zakonodavac. Naime, kako se čl. 126a. st. 2. hrvatskog ZPP-a prilikom određivanja mogućnosti stranaka da predlože tonsko snimanje ročišta koristi formulacijom prijedlog „stranaka“, sudac pojedinac ili predsjednik vijeća ne može odrediti tonsko snimanje ročišta na zahtjev samo jedne stranke. To ujedno implicira potrebu da su u slučaju tonskog snimanja ročišta iniciranom na prijedlog stranaka obje stranke suglasne s tonskim snimanjem. Kada bi tonsko snimanje ročišta određivao sud ex officio, suglasnost stranke ili stranaka s tonskim snimanje bila bi irelevantna. ${ }^{16}$

Strankama ne bi trebalo biti dopušteno tonsko ni video snimanje ročišta vlastitim uređajima. ${ }^{17}$

\section{POHRANA TONSKOG ZAPISA}

Odredbom st. 1. članka 375b. FZPP-a izrijekom je propisano da je tonska snimke ročišta dio spisa sudskog predmeta. To znači da će se tonski zapis unijeti u spis predmeta kronološkim redom i označiti rednim brojem u «popis spisa predmeta». Tonske/audio zapise $\mathrm{s}$ ročišta trebalo bi uložiti u omote spisa predmeta koristeći plastične košuljice koje se pričvršćuju na odgovarajući način (arg. Pravilnik o unutrašnjem sudskom poslovanju (,Službeni glasnik BiH“ broj 66/12 i 40/14, dalje Pravilnik, članak 44. st. 7.)

Odredbom članka 375b. FZPP-a uređuje se i način pohranjivanja tonske snimke te se istovremeno nalaže da se sudskim poslovnikom detaljnije urede način pohranjivanja, prijenosa tonske snimke, tehnički uvjeti i način snimanja.

To znači da odredbe o tonskom snimanju nisu izravno primjenjive u praksi. Potrebno je prije primjene ispuniti određene tehničke (faktične) i pravne pretpostavke. Osim toga, to znači da nisu svi problemi riješeni, neki niti naznačeni. Može se tako spomenuti povećani volumen spisa (zapisnik obuhvaća sve izgovoreno), povećanu potrebu za prepisivanjem, otežanu drugostupanjsku provjeru materijala i sl. ${ }^{18}$ Ostaje otvorena mogućnost odabira hoće li se snimati cijela rasprava ili ročište ili samo točno određeni dijelovi ročišta. S jedne strane, izbjegne li se tonsko snimanje cijele rasprave pa se snimaju točno određeni dijelovi ročišta (u skladu s odredbom članka 374. FZPP-a), udovoljilo bi se zakonskim pretpostavkama nužnim za sastavljanje zapisnika. S druge strane, budu li se rasprava ili ročište snimali od početka ročišta za raspravu do njegova okončanja, uzimajući u obzir obvezu da tonska snimke u pisanom obliku mora sadržavati sve što je tonski snimljeno, postupanje suda nakon provedenog tonskog snimanja iziskivalo bi dodatne personalne troškove potrebne radi pravodobnog prijenosa tonske snimke u pisani oblik i moguće stvaralo zbrku. ${ }^{19}$

16 Vidi Maganić, A., op. cit., str. 81.

17 U tom smislu vidi Smjernice općinskog suda u Sarajevu za postupanje u parničnom postupku, članak 26.

18 Vidi Bilić, V., op. cit., str. 80.

19 Tako Maganić, A., op. cit., str. 83. 


\section{NAČIN I OBLIK SAČINJAVANJA PISANOG OBLIKA TONSKOG ZAPISA}

Odredbama članka 375c. FZPP-a propisuju se način i rokovi sačinjavanja pisanog oblika tonske snimke, pravo stranaka na pisani prijepis te postupak ispravka prijepisa tonske snimke.

Tijekom ročišta parnične stranke i drugi sudionici u postupku usmeno iznose svoje činjenične tvrdnje, daju izjave i iskaze na okolnosti predmeta raspravljanja. Sve te usmeno iznesene činjenične tvrdnje, iskazi i izjave, koje su bitne za tijek parničnog postupka moraju na određeni način biti pisano dokumentirane u zapisnik s održanog ročišta. Odredbom čl. 375c. propisano je da sud mora tonska snimke prenijeti i u pisani oblik u roku osam dana od dana snimanja. Pisani oblik mora biti sačinjen u skladu s odredbama člana 374. FZPP-a kojima se uređuje sadržaj zapisnika, što znači da mora sadržavati: naziv suda, mjesto gdje se obavlja radnja, dan i sat kad se obavlja radnja, naznaka predmeta spora i imena nazočnih stranaka, odnosno trećih osoba (primjerice, umješači, svjedoci, vještaci), i njihovih zakonskih zastupnika, odnosno punomoćnika (FZPP, čl. 374. st. 1). ${ }^{20}$ Pisani oblik tonske snimke mora sadržavati mora sadržavati sve što je snimljeno u tonskoj snimci, a posebno bitne podatke o sadržaju poduzetih radnji (arg. FZPP, čl. 374. st. 2). ${ }^{21}$

\section{PRIJEPIS TONSKOG ZAPISA I PRIGOVOR STRANKE}

Stranke su ovlaštene tražiti prijepis tonske snimke u roku osam dana od dana kada je tonska snimke sačinjen. FZPP ne propisuje na koji način sud treba omogućiti strankama uvid u tonski zapis (kopija pisanog prijepisa, pravo na uvid u prostorijama suda i sl.) niti je propisan rok u kojemu sud mora udovoljiti tom zahtjevu, a nije predviđena mogućnost i razlozi zbog kojih sud eventualno ne bi udovoljio zahtjevu stranke. Iz dikcije odredbe st. 5. čl. 375c. FZPP-a dalo bi se zaključiti da bi sud strankama ipak trebao dostaviti prijepis tonske snimke. U svakom slučaju ove i druge dvojbe trebat će se detaljnije urediti u sudskom poslovniku.

Ako se prijepis tonske snimke i tonska snimke u bitnome razlikuju, stranka ima pravo podnijeti obrazloženi prigovor u roku osam dana od dana dostave prijepisa, a sud je o prigovoru dužan u roku od tri dana odlučiti rješenjem protiv kojega nije dozvoljena posebna žalba, a kojim sud može prigovor odbiti ili prihvatiti. Ako sud prihvati prigovor, dužan je izmijeniti prijepis tonske snimke (FZPP, čl. 375c.).

20 Iako je u odredbi čl. 374. st. 1. FZPP-a izostavljena sintagma „i sastav suda“ iz čl. 113. st. 1. SFZPP-a, vjerojatno zbog toga jer se smatrala nepotrebnom s obzirom na odredbu čl. 13. FZPP-a prema kojoj u prvostupanjskom postupku sudi sudac pojedinac, držimo ipak bitnim da se u zapisniku navodi podatak o osobama koje su prisutne od strane suda (sudac, zapisničar), jer taj podatak može biti značajan, među ostalim, i za kontrolu je li u donošenju odluke sudjelovao sudac koji nije sudjelovao na glavnoj raspravi, koji se po zakonu morao izuzeti ili je rješenjem suda bio izuzet. Čizmić, J., Komentar Zakona o parničnom postupku, 2. izdanje, Sarajevo, Privredna štampa, 2016., str. 1079-1081.

21 U st. 2. vjerojatno je došlo do redakcijske pogreške jer bi, radi smislenog tumačenje i primjene ovoga stavka, iza riječi „ovog zakona“ trebalo ubaciti slovo „i“. 


\section{ZAKON O KAZNENOM POSTUPKU, UPUTE SUDOVA I SUDSKI POSLOVNIK}

1. Odredbom čl. 88. st. 1. Pravilnika o unutrašnjem sudskom poslovanju (u daljnjem tekstu: Pravilnik), koji je donijelo Visoko sudsko i tužilačko vijeće Bosne i Hercegovine na sjednici održanoj 11. srpnja 2012. godine, regulirano je da se, u skladu s odredbama Zakona o kaznenom postupku, audio odnosno video snimanje glavnih pretresa vrši u skladu s uputom o snimanju glavnih pretresa i načinu rukovanja s audio odnosno video opremom u sudnici (koje je trebalo biti sastavni dio Pravilnika). Tako Zakon o kaznenom postupku Bosne i Hercegovine, (,Službeni glasnik Bosne i Hercegovine, br. 3/03, 32/03, 36/03, 26/04, 63/04, 13/05, 48/05, 46/06, 76/06, 29/07, 32/07, 53/07, 76/07, 15/08, 58/08, 12/09, 16/09, 93/09, 72/13“) u članku 155. i Zakon o kaznenom postupku Federacije Bosne i Hercegovine (Službene novine, FBiH br. 35/03, 37/03, 56/03, 78/04, 28/05, 55/06, 27/07, 53/07, 9/09, 12/10) u članku 169. na gotovo istovjetan način uređuju snimanje radnji poduzetih tijekom postupka uređajima za optičko i zvučno snimanje. Propisuju da se sve radnje poduzete tijekom kaznenog postupka u pravilu snimaju uređajem za zvučno snimanje o čemu tužitelj (državni odvjetnik) ili ovlaštena službena osoba prethodno trebaju obavijestiti osobu koja se ispituje i poučiti je da ima pravo zatražiti reprodukciju snimke kako bi provjerila svoju izjavu. Snimke mora sadržavati sve podatke koje mora sadržavati i pisani zapisnik (naziv organa pred kojim se obavlja radnja, mjesto gdje se obavlja radnja, dan i sat kad je radnja započeta i završena, imena i prezimena prisutnih osoba i u kojem svojstvu radnji prisustvuju, kao i oznaku kaznenog predmeta po kojem se poduzima radnja, sadržavati bitne podatke o toku i sadržaju poduzete radnje), kao i podatke potrebne za utvrđenje istovjetnosti osobe čija se izjava snima i podatak u kojem svojstvu ta osoba daje izjavu. Na zahtjev ispitane osobe snimke će se odmah reproducirati, a ispravke ili objašnjenja te osobe će se snimiti. U zapisnik treba unijeti da je obavljeno zvučno snimanje, tko je snimanje obavio, da je osoba koja se ispituje prethodno obaviještena o snimanju, da je snimke reproducirana i gdje se zvučna snimke čuva ako nije priložena spisima predmeta. Tužitelj (državni odvjetnik) može odrediti da se zvučna snimke u cjelini ili djelomično prepiše, te će prijepis pregledati, ovjeroviti i priključiti zapisniku. Zvučna snimke čuva se do vremena do kojeg se čuva i kazneni spis. Tužitelj (državni odvjetnik) može dozvoliti da osobe koje imaju opravdani interes snime izvođenje istražne radnje uređajem za zvučno snimanje. Snimke se ne mogu javno izvoditi bez pisanog odobrenja stranaka i sudionika snimljene radnje.

Za razliku od parničnog postupka, tijekom kaznenih postupaka u većini slučajeva osigurano je tonsko snimanje suđenja na način da se sve izjave i iskazi stranaka tijekom kaznenog postupka tonski snimaju i nakon toga se preslušavaju i pretipkavaju u autentičnom obliku u zapisnik s ročišta. Razlog zašto je tonsko snimanje zastupljeno u kaznenom postupku ali ne i u parničnom postupku, jeste taj što organizacijski na razini suda na kaznenom referatu radi znatno manji broj sudaca u odnosu na parnični referat, tako da je postupajućim sucima koji sude u kaznenom postupku moguće osigurati i odgovarajuću sudnicu kao i sva potrebna tehnička pomagala za tonsko snimanje tijeka kaznenog postupka, dok je na parničnom referatu potreban angažman 
većeg broja sudaca parničara pa samim time potrebne su i odgovarajuće sudnice i tehnička pomagala koja trenutno pravosudna zajednica nije u mogućnosti osigurati. Zbog toga tonsko snimanje ročišta još uvijek nije zaživjelo u sudovima, a parnični suci zbog nedostatka sudnica, prema našim saznanjima, suđenja organiziraju u vlastitim uredima površine oko $10 \mathrm{~m} 2$, u kojim ponekad ne mogu stati sve stranke i vještaci u postupku, a javnost, iako nije isključena, zbog tehničkih i organizacijskih razloga je u većini slučajeva spriječena ostvariti pravo na pristup ročištu tijekom suđenja (sukladno načelu javnosti).

2. Pravilnikom je nadalje posebno određeno da svaki sud može odlučiti snimati rasprave i u drugim sudskim predmetima (Pravilnik, čl. 88. st. 2.). U tom smislu predsjednici više sudova donijeli su uputstva/pravilnike o izradi $i$ čuvanju audio $i$ video snimki sačinjenih tijekom sudskog postupka (primjerice, Kantonalni sud u Livnu, Okružni sud u Banja Luci, Osnovni sud u Novom Gradu, Osnovni sud u Bijeljini, Općinski sud u Sarajevu i dr.). Njima se uređuje način izrade i čuvanja audio i video snimki sačinjenih tijekom sudskog postupka. Konkretno, tko obavlja snimanje, kada počinje i završava snimanje, rješavanje eventualnih tehničkih problema, upozorenja sudionicima postupka od strane postupajućeg suca, provjera tehničke ispravnosti snimljenog materijala, pohranjivanje i čuvanje snimljenog materijala te mogućnost izrada kopija snimljenog materijala. Tako se određuje da audio ili video snimanje sudskog postupka ili njegovih pojedinih faza (ročišta) obavljaju zapisničar (negdje asistent) i sudac u skladu sa zakonom. Zapisničar je dužan najmanje dvadeset minuta prije započinjanja radnje koja se snima provjeriti tehničku ispravnost opreme za audio ili video snimanje i o stanju te opreme odmah obavijesti postupajućeg suca. Ako to potrebe u pojedinom slučaju zahtijevaju, zapisničar i sudac mogu zatražiti stručnu i tehničku pomoć službenika za informacijsko-komunikacijske tehnologije u sudu - tehničkog operatera koji im je dužan u svakom slučaju pružiti traženu stručnu i tehničku pomoć.

Audio ili video snimanje počinje kada sudac ili članovi sudskog vijeća sjednu u sudnicu ili drugu prostoriju gdje se snimanje ima obaviti, a završava se njihovim izlaskom iz sudnice ili druge prostorije.

U slučaju kada dođe do tehničkog problema koji onemogućava snimanje sudskog postupka zapisničar je dužan o tome odmah obavijestiti postupajućeg suca ili predsjednika vijeća koji o tehničkom problemu trebaju odmah obavijestiti tehničkog operatora i zatražiti njegovu pomoć radi otklanjanja tehničkog problema. Za vrijeme otklanjanja tehničkog problema sudac ili predsjednik vijeća dužni su odrediti prekid u poduzimanju procesne radnje do otklanjanja tehničkog problema, a nakon otklanjanja tehničkog problema sudac ili predsjednik vijeća trebaju nastaviti prekinutu radnju u skladu sa zakonom. U slučaju kada se tehnički problem ne može otkloniti, a snimanje je već bilo započeto, sudac odnosno predsjednik vijeća može odlučiti da se započeta radnja odloži do otklanjanja tehničkog problema ili da se započeta radnja ponovo obavi bez audio ili video snimanja u slučaju kada je to zakonom dopušteno.

Prije poduzimanja radnje snimanja postupajući sudac dužan je upozoriti sve prisutne osobe čije izjave će se snimati da su prilikom davanja izjave dužni govoriti glasno u mikrofon, odnosno da su dužni šutjeti za vrijeme davanja izjave, te da mogu 
dobiti riječ tek nakon odobrenja suca ili predsjednika vijeća.

Zapisničar je dužan po završetku snimanja provjeriti tehničku ispravnost snimljenog materijala. U slučaju tehničke neispravnosti snimljenog materijala zapisničar je dužan o tome odmah obavijestiti postupajućeg suca i tehničkog operatera.

Audio ili video snimci čuvaju se u predmetnom spisu u posebnom zatvorenom omotu-koverti. Na omotu zapisničar označava: da se radi o audio ili video snimku, datum sačinjavanja snimke, poslovni broj spisa te kratki sadržaj snimke. Kratki sadržaj snimke označava se i na mediju, uz naznaku datuma i poslovnog broja spisa. Prije stavljanja snimke u omot zapisničar je dužan na samom mediju za pohranu podataka (CD i mini disk) označiti poslovni broj spisa kojem pripada taj medij ili datum prve radnje koja je snimljena na mediju. Nakon toga zapisničar je dužan omot pričvrstiti za spis. Otvaranje omota u kom se nalazi snimke može se obaviti samo uz prethodnu dozvolu postupajućeg suca, i o tome u spisu treba sačiniti službenu zabilješku.

$\mathrm{Na}$ zahtjev stranke, branitelja, punomoćnika stranke ili njezinog zakonskog zastupnika sud može, po odobrenju postupajućeg suca, dozvoliti izradu kopije audio materijala na CD. Osoba koja traži kopiju dužna je prethodno platiti novčanu naknadu. Kopiranje snimljenog materijala obavlja IKT-e tehničar suda. Izvorni snimljeni materijal po okončanom kopiranju treba vratiti u spis pri čemu postupajući sudac u spisu treba sačiniti službenu zabilješku o tome da je obavljeno kopiranje i na čiji zahtjev.

Kako su navedene upute u velikoj mjeri unificirana mogla bi poslužiti kao predložak za izmjene i dopune Pravilnika o unutrašnjem sudskom poslovanju (Sudskog poslovnika) te izradu uputa o snimanju glavnih pretresa i načinu rukovanja s audio, odnosno video opremom u sudnici koje je dužno izraditi VTSV (arg. Pravilnik, čl. 88. st. 1.).

3. Na temelju članka 17. točka 19. i 30. Zakona o Visokom sudskom i tužilačkom vijeću Bosne i Hercegovine (,Službeni glasnik BiH“, broj 25/04, 93/05, 48/07, 15/08), članka 37. stav 1. Zakona o sudovima u Federaciji Bosne i Hercegovine (,Službene novine FBiH“, broj 38/05, 22/06, 63/10, 72/10) i članka 33. stav 1. Zakona o sudovima Brčko Distrikta Bosne i Hercegovine ("Službeni glasnik Brčko Distrikta BiH“", broj 19/07, 20/07), Visoko sudsko i tužilačko vijeće Bosne i Hercegovine, na sjednici održanoj 11. 07. 2012. godine, donijelo je Pravilnik kojim se uređuje organizacija i način unutrašnjeg poslovanja općinskih i kantonalnih sudova, Osnovnog i Apelacijskog suda Brčko Distrikta BiH i Vrhovnog suda Federacije Bosne i Hercegovine (u daljnjem tekstu: sud) i druga pitanja značajna za unutrašnje sudsko poslovanje (Pravilnik, čl. 1.). Odredbom čl. 88. Pravilnika propisano je da se, sukladno odredbama Zakona o kaznenom postupku, audio odnosno video snimanje glavnih pretresa vrši u skladu s uputstvom o snimanju glavnih pretresa i načinu rukovanja s audio odnosno video opremom u sudnici (koje je trebalo biti sastavni dio Pravilnika). Usto, svaki sud ovlašten je odlučiti hoće li snimati rasprave i u drugim sudskim predmetima, i to na način koji treba biti predviđen navedenim uputstvom.

Pravilnik sadrži zasebni dio - poglavlje XVI - upotreba informacijskokomunikacijskih tehnologija u sudovima - u kojemu se uređuje: organizacija informacijsko-komunikacijskog sustava (dalje -IKT); načela korištenja IKT-a; 
uvođenje IKT-a u pravosudni sustav; pravosudni informacijski sustav; administracija pravosudnog informacijskog sustava; ${ }^{22}$ nadležnosti za administraciju; održavanje pravosudnog informacijskog sustava; ${ }^{23}$ korisnička podrška; ${ }^{24}$ elektronička pošta; ${ }^{25}$ pristup internetu. ${ }^{26}$ Bez informacijske i komunikacijske tehnologije nemoguće je pružiti visokokvalitetne i moderne sudske usluge koje će odgovoriti svim potrebama društva. ${ }^{27}$

22 Administracija Pravosudnog informacijskog sustava je kontinuirana djelatnost Sekretarijata i sudova, a podrazumijeva: instalaciju, konfiguraciju, nadzor i pravljenje rezervnih kopija svih komponenti sistema (Pravilnik, čl. 95.).

23 Pravosudni informacijski sustav obuhvaća sve IKT-e koje se uvode u sudove na osnovu propisa koje donese VSTV. Korisnici Pravosudnog informacijskog sustava su suci i drugi zaposlenici u sudu, članovi VSTV-a i zaposlenici u Sekretarijatu VSTV-a (u daljnjem tekstu: Sekretarijat). Federalno ministarstvo pravde Federacije $\mathrm{BiH}$, kantonalna ministarstva pravde te Pravosudna komisija Brčko Distrikta BiH kao korisnici pravosudnog informacijskog sustava imaju pravo pristupa statističkim izvještajima o radu sudova iz svoje nadležnosti u skladu s aktima VSTV-a kojima se regulira korištenje pravosudnog informacijskog sustava (Pravilnik, čl. 94.).

24 ,(1) Korisnička podrška predstavlja skup procesa i ljudskih potencijala angažiranih na pružanju podrške svim korisnicima Pravosudnog informacionog sistema u evidentiranju, analiziranju i rješavanju hardverskih i softverskih problema.

(2) VSTV posebnim uputstvom utvrđuje organizaciju, način pružanja i principe funkcioniranja sistema korisničke podrške.

(3) Ovlaštena lica u sudovima dužna su se pridržavati procedura iz uputstva iz stava (2) ovog člana, te izvještavati sekretara suda i VSTV o svim važnim problemima u funkcioniranju IKT sistema i mjerama poduzetim za njihovo rješavanje“ (Pravilnik, čl. 98.).

25 ,(1) Elektronska pošta Pravosudnog informacionog sistema omogućava razmjenu informacija i službenih podataka između sudaca, stručnih suradnika i ostalih zaposlenika u svim sudovima u BiH i VSTV-u.

(2) Putem ove elektronske pošte omogućena je i razmjena informacija i podataka sa svim ostalim korisnicima elektronske pošte na internetu.

(3) Sva interna obavještenja i informacije upućene sucima, stručnim suradnicima i ostalim zaposlenicima u sudu distribuiraju se elektronskom poštom Pravosudnog informacionog sistema.

(4) Suci, stručni suradnici i ostali zaposlenici dužni su svakog radnog dana provjeravati svoj pretinac elektronske pošte“" (Pravilnik, čl. 99).

26 "Sekretarijat kreira funkcionalan i siguran pristup internetu za sve sudove" (Pravilnik, čl. 100.).

27 O razvoju prava u području ICT-a vidi Rosonoer, J., Cyber Law: The Law of the Internet, New York, Springer-Verlag, 1996. 
Organizacijska struktura Odjela za IKT VSTV BiH koja obuhvata IKT/CMS projekt

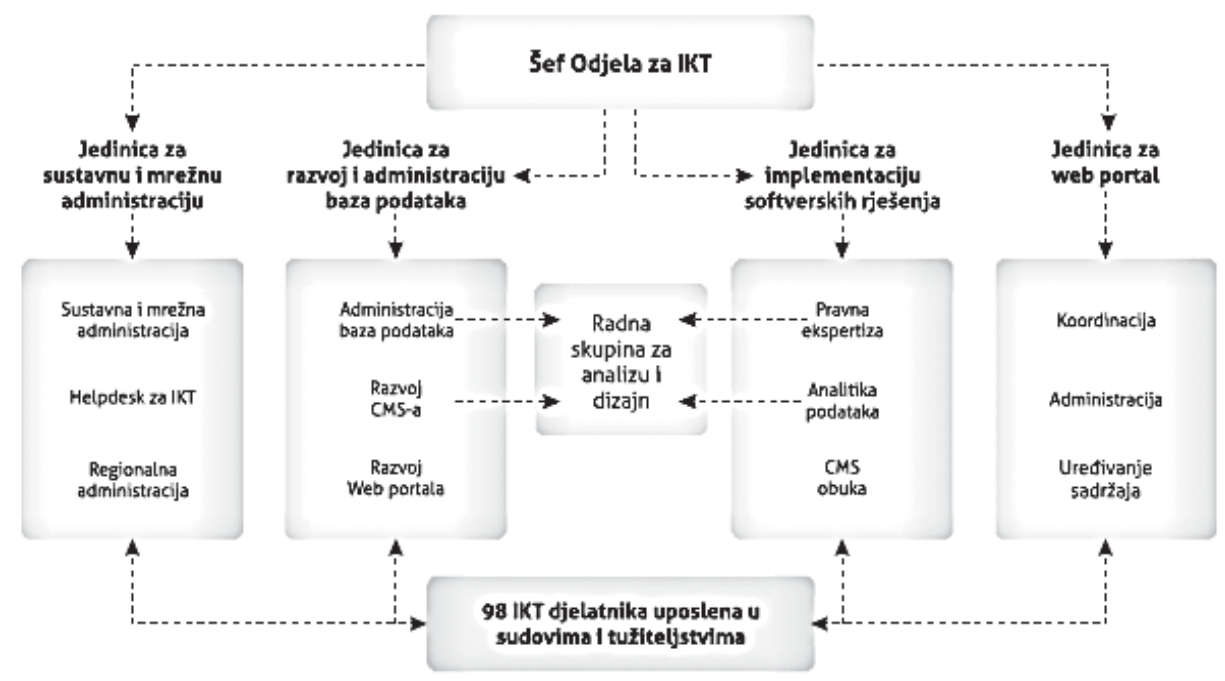

Slika 1. Organizacijska struktura Pravosudnog informacijskog sustava BiH (preuzeto sa https:// www.pravosudje.ba/vstv/faces/pdfservlet;jsessionid...?p_id_doc $=1649-02.01 .2019$.

Pravilnik se, dakle, detaljno bavi upotrebom informacijsko-komunikacijskih tehnologija u sudovima definirajući njihovo uvođenje, principe korištenja u sudovima i administraciju nadležnosti informacijsko-komunikacijskih tehnologija u sudovima u okviru pravosudnog informacijskog sustava Federacije Bosne i Hercegovine i Distrikta Brčko BiH. ${ }^{28}$ IKT (engl. kratica - ICT) se definiraju kao djelatnost i oprema koja čini tehničku osnovu za sustavno prikupljanje, pohranjivanje, obradbu, širenje i razmjenu informacija različita oblika, tj. znakova, teksta, zvuka i slike. Donedavno izolirana računala danas najvećim dijelom međusobno povezana u jedinstvenu računalnu mrežu, preko koje se velikom brzinom mogu razmjenjivati informacije, tekst, slike, zvuk i dr. ${ }^{29}$

Primjena informacijske tehnologije u pravu može se razmatrati u odnosu na pojedina pravna područja, kao što su pravosuđe, zakonodavstvo i javna uprava. Proces obrade pravnih podataka je pronalaženje osnovnih pravnih izvora. Ti izvori nalaze se kao pisana pravila u raznim zakonima, propisima i sudskim odlukama. Najnovija dostignuća na području primjene informacijske tehnologije u pravu kreću se u pravcu konstruiranja visoko sofisticiranih, tj. inteligentnih pravnih informacijskih sustava

28 O razvoju informacijskih sustava u tijelima javne vlasti vidi više u Šimundić, S., Boban, M., Development And Infomatization Of Regional And Local Governments, Proceeding Vol. V. DE \& ISS \& miproBIS \& LG \& SP, Čišić, D., et al. editor(s), Zagreb: Croatian Society for Information and Communication Technology, Electronics and Microelectronics - MIPRO, 2009., str. 263-267.

29 Definicija informacijsko-komunikacijskih tehnologija prema Brozović, D., Hrvatska enciklopedija, vol 5., Leksikografski zavod „Miroslav Krleža“, 1999., str. 111. 
primjenom tzv. umjetne inteligencije uz tehnološku podršku računala. ${ }^{30}$

U posljednjih nekoliko godina uložen je ogroman napor u razvoj i poboljšanje informacijskih sustava u pravosuđu koji omogućavaju lakše prikupljanje, dostupnost i obradu podataka čime se uspostavlja standardizacija pravosudnog sustava i osigurava pravna sigurnost građana. ${ }^{31}$ Informatizacija poslovnih procesa u pravosuđu podrazumijeva izgradnju integralnih informacijskih sustava s ključnim elementima koji daju podršku udaljenim lokacijama, omogućavaju dostupnost informacija u realnom vremenu, njihovu pouzdanost te sigurnost pristupa i sigurnost podataka. ${ }^{32}$

Što se nadležnosti VTSV-a u ovom području tiče, ono vodi, koordinira i nadgleda korištenje IKT-a u sudovima kako bi se u tom pogledu postigla i održala uniformnost u upotrebi IKT-a u Pravosudnom informacijskom sustavu Bosne i Hercegovine u svim sudovima. VSTV donosi pravilnike, upute i instrukcije kojima se regulira način korištenja IKT-a u sudovima, sigurnosne procedure, organizacija IKT podrške i druga pitanja u svezi s primjenom IKT-a u sudovima (Pravilnik, čl. 91.). ${ }^{33}$ VTSV odobrava i uvođenje novih softverskih i sistemskih rješenja u sudovima (Pravilnik, čl. 93.). VSTV utvrđuje pravila pristupa i korištenja interneta u službene svrhe (Pravilnik, čl. 100. st. 2.).

Administracija Pravosudnog informacijskog sustava ${ }^{34}$ definirana je kao kontinuirana djelatnost tajništva i sudova. Pravilnik pod administracijom podrazumijeva: instalaciju, konfiguraciju, nadzor i izradu rezervnih kopija svih komponenti sustava (Pravilnik, čl. 95.). Nadležnost za administraciju delegirana je Tajništvu, službenicima zaduženim za ICT u matičnim sudovima i višim sudovima (Pravilnik, čl. 96.). Rad administracije informacijskog sustava temelji se na zaštiti i

30 Vidi Raharanab, V., Introduction to information technology, PHI Learning Pvt. Ltd., 2018., str. 1-19; Evans, C., Kompjutorski izazov, Zagreb, 1982., str. 10.; Grbavac, V., Zagreb, Informatika, 1995., str. 1-8.

31 Vidi više u Council of Europe, Design of Court Systems and Legal Information Systems: Methods for Setting Up, Managing and Re-designing Systems in a Cost-effective Manner, Proceedings, 13th Colloquy on Legal Data Processing in Europe, Vienna (Austria), 15-17 April 1998, vol. 457, Council of Europe, 2000.

32 Preuzeto s mrežne poveznice https://pravosudje.gov.hr/pravosudni-sustav-11207/ministarstvopravosudja-11355/informacijski-sustavi-u-pravosudnim-tijelima/11393 (posjet 03. 01. 2018.).

33 ,(1) Sekretarijat administrira: a) servise u data centrima, b) opremu za povezivanje na pravosudnu mrežu širokog pojasa (ruteri, sistemi za obranu mreže od neovlaštenog upada, detekciju i prevenciju upada itd.), c) sisteme za autentifikaciju korisnika i infrastrukturnih servisa na serverima smještenim u sudovima, d) aktivne mrežne opreme (preklopnika) u LAN mrežama sudova.

(2) IKT službenici u matičnim sudovima administriraju: a) korisničke naloge za suci i administrativno osoblje, b) podatke pohranjene na serverima datoteka, c) radne stanice i print servere.

(3) IKT službenici u višim sudovima ovlašteni su da vrše administraciju iz stava (2) u sudovima sa svog područja, uz prethodno odobrenje predsjednika višeg suda i suda u kojem se administracija treba provesti““ (Pravilnik, čl. 96.).

34 Metodologija zaštite informacijskih sustava značajna je aspekt zaštite i sigurnosti svakog informacijskog sustava. O administraciji informacijskih sustava općenito vidi Portela, I. M., Organizational, Legal, and Technological Dimensions of Information System Administration, IGI Global, 2013. 
očuvanju sigurnosti podataka umreženih sustava i uklanjanju izvora opasnosti kojima je sustav izložen. Potrebno je istaknuti da apsolutna zaštita sustava i podataka ne postoji. Zato je korektnije smatrati da sustav zaštite ne omogućuje apsolutnu zaštitu podataka, već da se prije svega radi o metodama koje u velikoj mjeri umanjuju opasnosti kojima su izloženi. ${ }^{35}$

IKT se koriste u sudovima radi unaprjeđenja učinkovitosti njihovog rada. Korisnici IKT-a u sudovima dužni su poduzimati sve nužne mjere radi zaštite integriteta i sigurnosti IKT sustava pravosuđa i podataka koji su u njemu pohranjeni. ${ }^{36}$ IKT se koriste isključivo u službene svrhe u skladu s propisima koje donosi VSTV, a samo iznimno IKT se mogu koristiti u privatne svrhe ako takva upotreba ne ugrožava IKT sustav i ukoliko su za nju potrebni minimalni dodatni troškovi (Pravilnik, čl. 92.).

Pravilnik predviđa i korisničku podršku za osiguranje kontinuiranog rada pravosudnog informacijskog sustava. U tom smislu, korisnička podrška predstavlja skup procesa i ljudskih potencijala angažiranih na pružanju podrške svim korisnicima pravosudnog informacijskog sistema u evidentiranju, analiziranju i rješavanju hardverskih i softverskih problema. ${ }^{37}$ (Pravilnik, čl. 98., st. 1.) VSTV posebnom uputom utvrđuje organizaciju, način pružanja i principe funkcioniranja sistema korisničke podrške. (Pravilnik, čl. 98., st. 2.) prema kojoj su ovlaštene osobe u sudovima dužne postupati, te izvještavati tajnika suda i VSTV o svim važnim problemima u funkcioniranju IKT sustava i mjerama poduzetim za njihovo rješavanje. (Pravilnik, čl. 98., st. 3.)

35 Također, osnovne i potencijalne izvore opasnosti za opremu i podatke možemo svrstati u četiri kategorije: elementarne nepogode i druge slične pojave (požar, poplava, oluja, potres, i s1.), hardversko-softverske pogreške (pad sustava, tehničke pogreške i nedostatke na mrežnoj opremi i dr.), čovjeka s atributom nenamjernosti (loša organizacija, nehaj, nemar, ...) i čovjeka $\mathrm{s}$ atributom namjernosti (sabotaža, kriminal, špijunaža, vandalizam,...). Samim time Temeljne prijetnje u pravilu temeljene su upravo na faktoru ljudskih potencijala koji predstavljaju temeljenu prijetnju sigurnosti informacijskih sustava. Vidi šire Akmadžić, Z., str. 54-56.

36 U području prava, porast informacijskog okruženja predstavlja izazov pravnoj doktrini, ne samo u područjima kao što su ugovorno, stvarno, patentno i autorsko pravo, već i na novim područjima kao što je privatnost, zaštita osobnih podataka u računalnim informacijskim sustavima, međunarodni prijenos podataka i sama obrada podataka. Računala predstavljaju pravni izazov jer prenose obradu podataka u virtualni prostor koji donosi nove izazove kako za informacijsku tako i za pravnu znanost u obliku sigurnosti i zaštite podataka. U svakom slučaju, računala mogu pohranjivati podatke i obrađivati ih, a da to nije „vidljivo“. Upravo ta činjenica čini ih potencijalno nepredvidljivim, a samim time i izvorom sigurnosnih ugroza u smislu čuvanja povjerljivosti i integriteta podataka. Mogućnost računala da praktično, bez ograničenja u vremenu i prostoru, reproducira podatke i to u beskonačnim varijantama zapravo je izazov. Pravna regulativa pak pokušava determinirati izvore opasnosti (primjerice, u obliku računalne prijevare ili krađe identiteta) i sankcionirati sve oblike neovlaštenog pristupa kako informacijama tako i informacijskim sustavima u ovom slučaju s naglaskom na pravosudne informacijske sustave. O razvoju pravosudnih informacijskih sustava vidi Bankowski, Z., White, I., Hahn, U., Informatics and the Foundations of Legal Reasoning, Springer Science \& Business Media, 9. ožujak 2013.

37 Vidi Council of Europe, Information Technology and Law: Linking Systems and Their Users: Modern Communication Techniques in the Legal Field Proceedings, Council of Europe, 2001. 


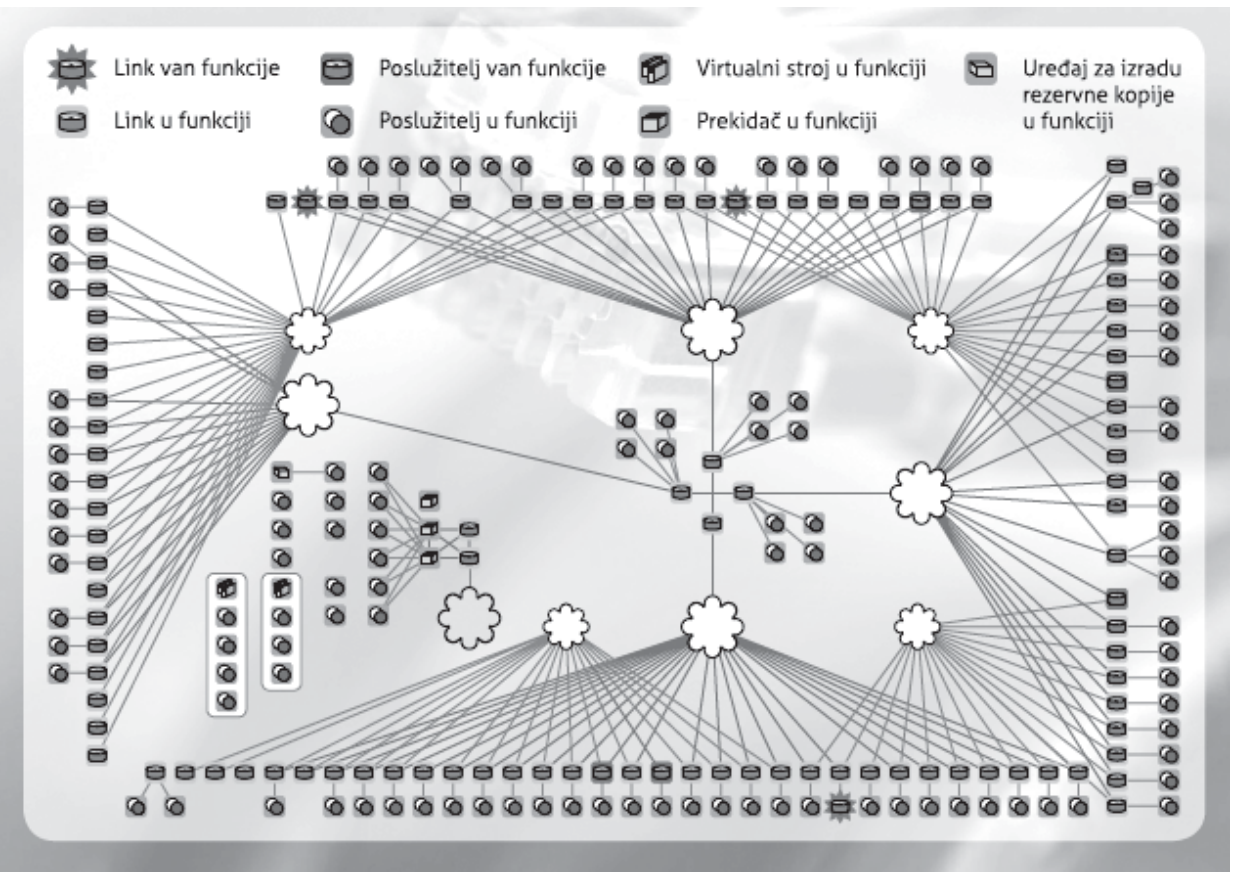

Slika 2. Shematski prikaz između informacijskih sustava sudova i tužiteljstava u Bosni $i$ Hercegovini- infrastrukturna potpora: centralizirano upravljanje mrežom (preuzeto sa https:// www.pravosudje.ba/vstv/faces/pdfservlet;jsessionid...?p_id_doc $=1649-02.01 .2019$.)

Poseban naglasak stavljen je i na elektroničku poštu (engl. e-mail) Pravosudnog informacijskog sustava kojom se omogućava razmjena informacija i službenih podataka između sudaca, stručnih suradnika i ostalih zaposlenika u svim sudovima u BiH i VSTV-u. (Pravilnik, čl. 99., st. 1.) Putem elektroničke pošte omogućena je i razmjena informacija i podataka sa svim ostalim korisnicima elektroničke pošte na internetu. (Pravilnik, čl. 99., st. 2.) kao i sve interne obavijesti i informacije upućene sucima, stručnim suradnicima i ostalim zaposlenicima u sudu koje se distribuiraju elektroničkom poštom Pravosudnog informacijskog sustava. (Pravilnik, čl. 99., st. 3.) Pravilnik nalaže i redovitu provjeru elektroničke pošte svakog radnoga dana za suce, stručne suradnike i ostale zaposlenike. (Pravilnik, čl. 99., st. 4.)

Održavanje Pravosudnog informacijskog sustava provodi tajništvo i sudovi kroz organizacijom i financiranjem redovitog servisiranja hardverskih komponenti i obnavljanja softverskih licencija, te otklanjanje hardverskih kvarova na svim komponentama sustava. ${ }^{38}$ Tajništvo održava sve hardverske i softverske komponente u podatkovnim centrima, a sudovi osiguravaju održavanje IKT opreme i softverskih licencija koje se nalaze u vlasništvu suda. Također, tajništvo i sudovi dužni su voditi urednu dokumentaciju o stanju IKT opreme i njezinom servisiranju, a tajništvo po

38 O načinima održavanja suvremenih pravosudnih sustava i o implementaciji pravosudnih sustava općenito vidi više u Wyner, A., Casini, G., Legal Knowledge and Information Systems, JURIX 2017: The Thirtieth Annual Conference, IOS Press, 2017., str. 142-144 
potrebi pruža tehničku pomoć sudovima u pogledu organizacije servisiranja opreme. Svi su sudovi dužni izraditi i dostaviti godišnji izvještaj za prethodnu godinu o stanju IKT opreme (Pravilnik, čl. 97.).

\section{ZAKLJUČ AK}

Postojeći način tonskog snimanja u sudovima odvija se na način da se najprije izvrši tonski audio zapis svih izjava i iskaza stranaka u postupku, nakon čega osoblje suda vrši preslušavanje audio snimke a potom njegov prijepis. Tako pretipkana tonska snimke zajedno s izvornom audio snimkom postaje sastavni dio zapisnika s održanog ročišta. Ovakav način tonskog snimanja ne isključuje u potpunosti grešku u pogledu autentičnosti zapisa u odnosu na audio snimke, s obzirom na to da nakon tonskog snimanja dolazi do fizičkog preslušavanja audio snimke i njegova prijepisa u pisani tekst, a taj način ostavlja mogućnost da se prilikom preslušavanja i prijepisa neka riječ ispusti ili pogrešno prepiše što može ponekad promijeniti smisao onoga što je stranka željela i imala namjeru istaknuti kao bitno tijekom postupka. Kako bi se izbjegle sve moguće situacije koje dovode u pitanje autentičnost iskaza i tvrdnji tijekom ročišta, idealno bi bilo da pravosudna zajednica svake države osigura računalni program namijenjen za potrebe pravosuđa, a koji bi imao mogućnost pretvarati glas u tekst. ${ }^{39}$ U tom slučaju sve izjave, iskazi te činjenične tvrdnje istaknute tijekom ročišta bi po automatizmu računalno bili pretvarani u tekst, što bi dovelo do potpune autentičnosti usmeno iznesenog iskaza kako parničnih stranaka u postupku i drugih sudionika. S druge strane, ročište bi trajalo znatno kraće što bi u pogledu radnog vremena rasteretilo sud od poslova organizacijske prirode. Takvo snimanje suđenja između ostalog uspostavilo bi i red u sudnici te bi osiguralo elementarnu pristojnost $\mathrm{u}$ ponašanju stranaka i suda. Tada bi se stranke suzdržavale od ekscesnih postupaka jer takvo tonsko snimanje bi omogućilo sankcioniranje svake zlouporabe procesnih prava. Također, stupanj sumnje u pristranost postupajućeg suca i zapisničara bio bi sveden na minimum. Poznato je da stranke u sudskom postupku na razne načine opstruiraju njegov tijek. Tonsko snimanje suđenja na opisani način doprinijelo bi da u postupcima bude uveden red. Također ako bi tonsko snimanje bilo uvedeno kao obvezatni način održavanja i vođenja ročišta, $u$ potpunosti bi bila postignuta autentičnost onoga što su stranke iznijele tijekom postupka, a što je kvalitetna pretpostavka za donošenje ispravne odluke.

Nedvojbeno je da u Federaciji Bosne i Hercegovine postoji pravni okvir za tonsko snimanje ročišta u parničnom postupku, ali je nedostatan. Istina je da postoje odredbe članaka 375a, 375b. i 375c. FZPP-a kojima se uređuje tonsko snimanje ročišta, ali je za njihovu pravilnu i svrsishodnu primjenu, što se pravnog okvira tiče, još potrebno donijeti ili dopuniti i neke podzakonske propise. Tako bi VTSV treba

39 U tom smislu na Konferenciji "Pravosuđe - trenutno stanje i perspektiva" održanoj u Mostaru 5. i 6. 12. 2018., u okviru Radne grupe I - Učinkovitost i kvalitet sudova i tužilaštava, donesen je, među ostalim, i zaključak broj 8 , da se s ciljem učinkovitijeg vođenja postupaka razmotri unapređenje postojećih i uvođenja novih tehnologija, kao npr. aplikacija za prevođenje govora u tekst te stvaranja uvjeta za tonsko snimanje svih postupaka koji se vode pred sudovima. 
donijeti upute o snimanju glavnih pretresa i načinu rukovanja s audio odnosno video opremom u sudnici, kao što je to najavljeno u članku 88. Pravilnika, a i odredbama članka 375b. FZPP-a kojima se uređuje način pohranjivanja tonske snimke, nalaže se da se sudskim poslovnikom detaljnije urede način pohranjivanja, prijenosa tonske snimke, tehnički uvjeti i način snimanja. U tom smislu trebat će dopuniti i odredbe Pravilnika (Sudskog poslovnika) u dijelu kojim se uređuje upotreba informacijskokomunikacijske tehnologija u sudovima jer se njima sada ova materija uređuje na općenit način i postojeće odredbe ne razrađuju detaljnije institut tonskog snimanja ročišta u parničnom postupku, što je razumljivo budući da odredbe članaka 375a, 375b. i 375c. FZPP-a o tonskom snimanju ročišta donesene nakon donošenja Pravilnika.

Ovaj je zadatak ponajprije u nadležnosti VTSV-a jer ono koordinira uporabu informacijskih tehnologija u sudovima radi ostvarivanja ujednačenosti, a sud može uvesti automatizirani sustav praćenja ili registracije predmeta, ili drugi sustav upravljanja predmetima, uključujući sustave sigurnosne pohrane i čuvanja podataka, samo uz prethodno odobrenje VTSV-a. ${ }^{40}$

Osim nužnog uređenja pravnog okvira, niz je drugih problema tehničke, organizacijske i financijske prirode koje je potrebno riješiti kako bi se mogle učinkovito primjenjivati odredbe FZPP-a o tonskom snimanju.

Naime, unatoč odredbama FZPP-a kojima se uvodi mogućnost tonskog snimanja ročišta u parničnom postupku, takva praksa još uvijek nije zaživjela na parničnom referatu, pa se rasprave tonski ne snimaju, ponajprije zbog toga što sudnice još uvijek nisu odgovarajuće opremljene. Prema našim saznanjima jedino se na općinskom sudu u Sarajevu i to samo iznimno (kada ima velik broj stranaka, svjedoka i drugih sudionika u postupku) rasprave tonski snimaju, $\mathrm{s}$ time da je i takva mogućnost snimanja ograničena jer se unaprijed mora rezervirati i organizirati sudnica koja je opremljena za tonsko snimanje. Stoga je nužno osigurati da na svakom sudu bude opremljena barem jedna sudnica za tonsko snimanje, jer bi se na takav način rasprave puno lakše i brže završavale, a to bi dovodilo i do racionalnijeg iskorištavanja radnog vremena i na koncu do bržeg i učinkovitijeg postupanja suda.

Kada su u pitanju parnični postupci može se slobodno konstatirati da način vođenja ročišta putem tonskog snimanja nije uopće zaživio upravo iz razloga što u sudovima nedostaju nužne prostorije, odnosno dostatan broj sudnica, a ne postoji ni potrebna tehnička oprema za tonsko snimanje ročišta, zbog čega se sva ročišta odvijaju i dalje na način da stranke, svjedoci, vještaci usmeno na zapisnik iznose svoja zapažanja nakon čega zapisničar uz pomoć postupajućeg suca te usmeno iznesene činjenice, izjave i druge iskaze zapisničarskim tipkanjem unosi u zapisnik, u pravilu u njihovom izvornom obliku i sadržaju. Međutim ponekad su ti iskazi, izjave i tvrdnje takve da je nužna intervencija suca kako bi interpretirao što je stranka željela i htjela tijekom ročišta kazati i istaknuti.

Neki razlog neprimjenjivanja odredbi o tonskom snimanju ročišta vide i u tomu što suci to ne žele budući da suci sada, pogotovo u parnicama gdje nema vijeća, sami interpretiraju u zapisnik iskaze svjedoka i stranaka i lako mogu njima manipulirati,

40 Arg. Zakon o sudovima u Federaciji Bosne i Hercegovine, Službene novine FBiH, br. 38/05, 22/06 i 63/10, s ispravkom u br. 72/10, 7/13. 52/14, članak 67. 
odnosno unositi izjave kakve oni žele. Drže da je apsurdno ostaviti sudu odluku o tonskom snimanju ročišta, a da stranke nemaju na takvu odluku pravo na žalbu. ${ }^{41}$ U tom smislu u jednom zahtjevu za izuzeće suca tuženik kao razloge za izuzeće navodi to ,što je Ministarstvo pravosuđa RH osiguralo sredstva za tonsko snimanje ročišta, a koje nije postavljeno, niti omogućeno, što omogućava pojedinim sucima i sudskim savjetnicima da sastavljaju zapisnike na način kako im to određuju pojedini punomoćnici stranaka, što je vidljivo iz zapisnika“" 42

Za učinkovitu primjenu odredaba FZPP-a o tonskom snimanju ročišta trebalo bi dodatno educirati osobe odgovorne za tonsko snimanje (zapisničare, asistente pa i postupajuće suce), na svakom sudu treba zaposliti IKT tehničare te prilagoditi sudnice tonskom snimanju. Naime, uočeno je da sudski zapisničari nisu do kraja obučeni za rad na tom sustavu, da na sudovima nedostaje potpuna i odgovarajuća oprema za tonsko snimanje, da postoje tehničke teškoće poput velike jeke u sudnicama i sl. ${ }^{43}$

Niz problema vezan je za prepisivanje snimke rasprave. Nema dvojbi da je, kada se rasprava snima i kada se u zapisnik koji se vodi uz takvo snimanje unose samo najvažniji podaci o tijeku rasprave, a ne i bitan sadržaj izjava stranaka i provedenih dokaza (pri čemu se ponajprije misli na one personalne - iskaze svjedoka, vještaka i optuženika), potrebno izraditi i prijepis takve snimke koji će sadržavati cjelovite izjave i iskaze svih sudionika u tom dijelu postupka. Pritom, naravno, treba uzeti u obzir i činjenicu da prepisivanje snimke rasprava, ako bi se češće koristilo takvo snimanje, iziskuje novu organizaciju rada sudova. ${ }^{44}$

\section{LITERATURA}

Knjige i članci:

- knjige:

1. Akmadžić, Zoran, Zagreb, Informacijski sustav MUP-a RH, 1998.

2. Bankowski, Zenon, White, Ian, Hahn, Ulrike, Informatics and the Foundations of Legal Reasoning, Springer Science \& Business Media, 2013.

3. Brozović, Dalibor, Hrvatska enciklopedija, vol. 5, Zagreb, Leksikografski zavod „Miroslav Krleža“, 1999.

4. Evans, Cristopher, Kompjutorski izazov, Zagreb, 1982.

5. Grbavac, Vitomir, Zagreb, Informatika, 1995.

41 Vidi: Potrošili više od milijun eura na opremu za snimanje, a suci je uporno odbijaju koristiti! Podatak na mrežnoj stranici: https://slobodnadalmacija.hr/novosti/hrvatska/clanak/id/275210/ potrosili-vise-od-milijun-eura-na-opremu-za-snimanje-a-suci-je-uporno-odbijaju-koristiti; posjet 27. 12. 2018.

42 Odlučujući o zahtjevu za izuzeće predsjednik suda je našao da tvrdnje tuženika nisu takve naravi da bi dovele u sumnju nepristranost i objektivnost suca te ne mogu predstavljati razlog za njegovim izuzećem. Rješenje predsjednika suda, Broj: Su-IV-191/17-2., podatak na stranici: https://sudskapraksa.csp.vsrh.hr/decisionText?id=090216ba8073f86a\&q=tonsko+snimanje; posjet 27. 12. 2018.

43 Tako Potrošili više od milijun eura na opremu za snimanje, a suci je uporno odbijaju koristiti! Podatak na stranici: https://slobodnadalmacija.hr/novosti/hrvatska/clanak/id/275210/potrosilivise-od-milijun-eura-na-opremu-za-snimanje-a-suci-je-uporno-odbijaju-koristiti; posjet 27. 12. 2018.

44 Usp. Tripalo, D., op. cit., str. 82.-83. 
6. Portela, Irene Maria, Organizational, Legal, and Technological Dimensions of Information System Administration, IGI Global, 2013.

7. Rosenoer, Jonathan, Cyber Law: The Law of the Internet, New York, Springer-Verlag, 1996.

- članci

1. Bilić, Vanja, Troškovi postupka, dostava i tonsko snimanje glavne rasprave prema Zakonu o izmjenama i dopunama ZPP-a 2011., u knjizi: Vanja Bilić i dr., Novela Zakona o parničnom postupku iz 2011, Zagreb, Novi informator, 2011.

2. Council of Europe, Design of Court Systems and Legal Information Systems: Methods for Setting Up, Managing and Re-designing Systems in a Cost-effective Manner, Proceedings, 13th Colloque on Legal Data Processing in Europe, Vienna (Austria), 15-17 April 1998, vol. 457, Council of Europe, 2000.

3. Council of Europe, Information Technology and Law: Linking Systems and Their Users: Modern Communication Techniques in the Legal Field Proceedings, Council of Europe, 2001.

4. Čizmić, Jozo, Komentar Zakona o parničnom postupku, drugo izmijenjeno i dopunjeno izdanje, Sarajevo, Privredna štampa, 2016.

5. Dika, Mihajlo, Novela Zakona o parničnom postupku iz 2011. - Opći pregled, u knjizi Vanja Bilić i dr., Novela Zakona o parničnom postupku iz 2011., Zagreb, Novi informator, 2011.

6. Kontrec, Damir, Žalba protiv presude, u knjizi Vanja Bilić i dr., Novela Zakona o parničnom postupku iz 2011., Zagreb, Novi informator, 2011.

7. Kulenović, Z., Zakon o parničnom postupku Republike Srpske, Domaća i strana sudska praksa - stručni i informativni časopis, god. XI, 60/2014.

8. Maganić, Aleksandra, Elektroničko vođenje postupka, u knjizi Mihajlo Dika i dr., Novosti u parničnom postupku - Zakon o izmjenama i dopunama Zakona o parničnom postupku (NN br. 57/11), Zagreb, Organizator d.o.o. 2011.

9. Rajaraman, V., Introduction to information technology, PHI Learning Pvt. Ltd., 2018., str. 1-19.

10. Šimundić, Slavko, Boban, Marija, Development and Infomatization of Regional and Local Governments, Proceeding Vol. V. DE \& ISS \& miproBIS \& LG \& SP, Dragan Čišić et al. editor(s). Zagreb: Croatian Society for Information and Communication Technology, Electronics and Microelectronics - MIPRO, 2009., str. 263-267.

11. Tripalo, Dražen, Snimanje ispitivanja osumnjičenika i snimanje rasprave prema prijedlogu ZID ZKP iz 2017. (7. Novela), Zbornik Novine u kaznenom zakonodavstvu - 2017., ur. Ana Garačić, Opatija, 11.-12. svibnja 2017., str. 82-83.

12. Wyner, Adam, Casini, Giovanni, Legal Knowledge and Information Systems, JURIX 2017: The Thirtieth Annual Conference, IOS Press, 2017., str. 142-144.

Vrela s interneta

1. Ministarstvo pravosuđa Republike Hrvatske, službene mreže stranice, https://pravosudje. gov.hr/pravosudni-sustav-11207/ministarstvo-pravosudja-11355/informacijski-sustavi-upravosudnim-tijelima/11393

Pravni akti

- pravni izvori različitih država

Bosna i Hercegovina

1. Prijedlog izmjena i dopuna Zakona o parničnom postupku, Radna grupa za izmjene i dopune ZPP u BiH, RS, FBiH i Brčko Distriktu BiH, Ilidža - 4. i 5. 2012. godine

2. Prijedlog zakona o izmjenama i dopunama Zakona o parničnom postupku Federacije Bosne i Hercegovine sa Obrazloženjem, Vlada Federacije Bosne i Hercegovine, Sarajevo, 2015.

3. Procjena zakona o parničnom postupku u Bosni i Hercegovini, OSCE, Sarajevo 2011. 


\section{Jozo Čizmić* \\ Marija Boban**}

Summary

\section{TONE RECORDING OF THE HEARING BEFORE THE COURTS OF THE FEDERATION OF BOSNIA AND HERZEGOVINA}

According to Article 98 of the Law on Civil Procedure of the Federation of Bosnia and Herzegovina in 2015, the existing legal text has been supplemented by the new articles $375 \mathrm{a}, 375 \mathrm{~b}$. and $375 \mathrm{c}$. which introduces the possibility of tone recording of litigation. The proposed articles regulate the manner in which the court proceeds in conducting the tone recording, and their purpose is to improve the efficiency of court proceedings and to increase the credibility of presenting evidence in litigation proceedings. In this paper, the authors referred to: the reasons and aim of regulating the tone recording of litigation, the manner and procedure of making a decision on the tone recording of the hearing, the storage of the recorded tone, the making of the transcript of the tone and the possibility of the party's objection, other relevant regulations regulating the sound recording (The Criminal Procedure Act, Courts Instructions, Courts rules of procedure), and in conclusion have pointed out a number of issues that make it difficult and disable the tone recording of litigation with suggestions that such a way of documenting factual allegations, statements and statements of litigants in civil proceeding will make more efficient.

Keywords: tone recording; hearing; information and communication technology (ICT); litigation.

Zussamenfassung

\section{TONAUFNAHME DER GERICHTSVERHANDLUNG IN DER FÖDERATION BOSNIEN UND HERZEGOWINA}

Durch Artikel 98 der Novelle des Zivilprozessgesetzes der Föderation Bosnien und Herzegowina aus dem Jahr 2015 wurde der bestehende Gesetzestext durch neue Artikel 375a, 375b und 375c ergänzt, welche die Tonaufnahme der Verhandlung im Zivilprozess ermöglichen. Die vorgeschlagenen Artikel regulieren das

* Jozo Čizmić, Ph.D., Full Professor, Faculty of Law, University of Split; jozo.cizmic@pravst.hr. ** Marija Boban, Ph.D., Associate Professor, Faculty of Law, University of Split; marija.boban@ gmail.com. 
Vorgehen des Gerichts bei der Durchführung der Tonaufnahme mit dem Ziel, die Effizienz des Gerichtsverfahrens und die Glaubwürdigkeit des Beweisverfahrens zu verbessern. Der Beitrag bespricht die Gründe und das Ziel der Regulierung der Tonaufnahme der Verhandlung im Zivilprozess, die Art und Weise und das Verfahren der Entschlussfassung über die Tonaufnahme der Verhandlung, die Bewahrung der Tonaufnahme, die Erstellung der Abschrift der Tonaufnahme und die Möglichkeit des Einspruchs der Partei sowie auch andere relevante Vorschriften, durch welche die Tonaufnahme von Verhandlungen geregelt wird (Strafprozessordnung, Gerichtsanweisungen und Verfahrensordnung des Gerichts). Abschließend wird auf zahlreiche Probleme, welche die Tonaufnahme der Verhandlung im Zivilprozess erschweren oder unmöglich machen, hingewiesen. Es werden auch Vorschläge gegeben, wie man solche Dokumentation von Aussagen über Tatsachen und Erklärungen von Zeugen im Zivilprozess effizienter machen kann.

Schlüsselwörter: Tonaufnahme; Verhandlung; Informations- und Kommunikationstechnologien (IKT); Zivilprozess.

Riassunto

\section{LA REGISTRAZIONE AUDIO DELLE UDIENZE DINANZI ALLE CORTI DELLA FEDERAZIONE DI BOSNIA ED ERZEGOVINA}

Con l'articolo 98 della novella della legge sul processo civile della Federazione di Bosnia ed Erzegovina del 2015 è stato integrato il testo legislativo esistente con i nuovi articoli $375 \mathrm{a}, 375 \mathrm{~b}$ e $375 \mathrm{c}$ con i quali viene introdotta la possibilità della registrazione audio delle udienze nel processo civile. Gli articoli proposti disciplinano la modalità di operato del tribunale in occasione della registrazione audio nell'intento di migliorare l'efficienza del procedimento giudiziale ed una maggiore affidabilità del procedimento probatorio. Nel lavoro gli autori si sono concentrati su: motivi e scopi della disciplina della registrazione audio delle udienze nel processo civile; modalità e processo decisionale circa la registrazione audio; conservazione delle registrazioni audio; redazione della trascrizione della registrazione audio e possibilità di reclamo della parte; altre rilevanti disposizioni di legge che regolano la registrazione audio di dibattimenti giudiziali (Legge sulla procedura penale, istruzioni dei tribunali e regolamento del tribunale). Nelle conclusioni si illustrano dei di problemi che rendono difficoltoso ed impossibile la registrazione audio nel processo civile con delle proposte su come rendere più efficaci tali metodi di documentazione di affermazioni, circostanze e dichiarazioni dei soggetti inclusi nel processo civile.

Parole chiave: registrazione audio; udienza; tecnologie informatiche e della comunicazione; processo civile. 